\title{
Perancangan Aplikasi Pembelajaran Matematika Menggunakan Teknologi Augmented Reality Dengan Database Marker Cloud Recognition Berbasis Android Pada Sd Inpres Paccerakkang Makassar
}

\author{
Wahyudi, Muhardi,Muh. Syahlan \\ STMIK Dipanegara Makassar \\ Jl. Perintis Kemerdekaan Km. 9, (0411-587149)
}

\begin{abstract}
Abstrak
Aplikasi Pembelajaran Matematika Menggunakan Teknologi Augmented Reality dibangun untuk mempermudah para guru Sekolah Dasar khususnya di bidang matematika mengajarkan materi serta menambah ketertarikan anak Sekolah Dasar dalam belajar mengenai rumus matematika Sekolah Dasar. Pada tahapan awal pembuatan Aplikasi Pembelajaran Rumus Matematika Menggunakan Teknologi Augmented Reality Dengan Database Marker Cloud Recognition Berbasis Android Pada SD Inpres Paccerakkang, dimulai dengan tahapan analisis data, perancangan sistem, dan juga perancangan interface. Aplikasi Pembelajaran Rumus Matematika Menggunakan Teknologi Augmented Reality dibangun dengan menggunakan Android Development Tools untuk pengembangan algoritma- algoritma, Blender 3D sebagai pembuat 3D objek, CorelDRAW sebagai editor desain user interface, dan Unity 3D sebagai editor script. Aplikasi Pembelajaran Rumus Matematika Menggunakan Teknologi Pembelajaran Matematika Menggunakan Teknologi Augmented Reality Dengan Database Marker Cloud Recognition Berbasis Andoroid Pada SD Inpres Paccerakkang akan dapat membantu tidak hanya memberikan pembelajaran secara umum dan dilingkungan anak Sekolah Dasar tetapi di masyarakat umum yang ingin mengetahui Rumus Matematika Augmented Reality dapat berjalan pada smartphone Android. Pengembangan dari sistem ini diharapkan Aplikasi yang terdapat di Bangku Sekolah Dasar.
\end{abstract}

Kata kunci: Augmented Reality, Cloud Recognition, Android

\begin{abstract}
Mathematics Learning Application Using Augmented Reality Technology was built to make it easier for elementary school teachers, especially in the field of mathematics to teach material and increase the interest of elementary school children in learning about elementary school math formulas. In the initial stages of making Learning Applications Mathematical Formulas Using Augmented Reality Technology with an Android-based Cloud Recognition Marker Database at SD Inpres Paccerakkang, starting with the stages of data analysis, system design, and interface design. Learning Applications Mathematical Formulas Using Augmented Reality Technology are built using Android Development Tools for algorithm development, Blender 3D as a 3D object maker, CorelDRAW as a user interface design editor, and Unity $3 D$ as a script editor. Learning Applications Mathematical Formulas Using Augmented Reality Technology can run on Android smartphones. Development of this system is expected that Mathematics Learning Application Using Augmented Reality Technology with Andoroid Based Cloud Recognition Marker Database at SD Inpres Paccerakkang will be able to help not only provide learning in general and in elementary school children but in the general public who want to know the Mathematical Formulas in the Bench Primary school.
\end{abstract}

Keywords: Augmented Reality, Cloud Recognition, Android

\section{PENDAHULUAN}

Matematika merupakan salah satu mata pelajaran yang memerlukan ketelitian dalam mempelajarinya, terutama saat mengerjakan soal-soal Matematika, siswa sering merasa kesulitan dalam memahami soal. Matematika juga merupakan ilmu yang mencakup aplikasi yang luas dalam aspek kehidupan. Perlu adanya penyampaian contoh soal serta penjelasannya dan kegiatan yang dipersiapkan hendaknya dilakukan dalam situasi yang lebih menarik dan menyenangkan serta mudah diterima 
terkhusus pada SD Inpres Paccerakkang. SD Inpres Paccerakkang merupakan salah satu SD yang berada di wilayah kecamatan Biringkanaya kota Makassar dengan jumlah siswa 797 dengan 401 siswa laki-laki dan 396 siswa perempuan. Dengan dipengaruhi media dan teknologi yang digunakan para siswa SD Inpres Paccerakkang dapat menumbuhkan semangat belajar mereka.

Saat ini siswa SD Inpres Paccerakkang memiliki minat yang kurang dalam belajar matematika dikarenakan media pembelajaran yang saat ini digunakan masih didominasi oleh buku yang berisi tulisan dan gambar saja. Oleh karena itu inovasi dalam pembelajaran dan strategi pembelajaran Matematika perlu dilakukan. Sering kali dengan banyaknya jam pelajaran Matematika dibandingkan jam mata pelajaran lain dan banyaknya materi yang ada membuat siswa merasa jenuh dan bosan dalam belajar Matematika, ditambah lagi dengan penyampaian guru yang lebih mengacu pada teori-teori Matematika yang banyak dan kompleks.

Maka berawal dari permasalahan tersebut alasan dipilihnya judul penelitian ini diharapkan akan memberikan suatu solusi untuk masalah diatas. Pemanfaatan alat peraga berbasis teknologi $2 D$ dan $3 D$ sangat bermanfaat dalam meningkatkan proses belajar mengajar karena teknologi $2 D$ dan $3 D$ memiliki aspek-aspek hiburan yang dapat menggugah minat peserta didik untuk memahami secara kongkret mengenai materi yang disampaikan melalui representasi visual $3 D$ dengan melibatkan interaksi user dalam media pembelajaran. Dengan adanya tampilan aplikasi yang menarik dan tampilan soal yang acak akan membuat proses belajar mengajar lebih menarik dan tidak akan merasa bosan.

Atas dasar itulah diharapkan dengan dibuatnya Aplikasi Pembelajaran Matematika Menggunakan Teknologi Augmented Reality dengan Database Marker Cloud Recognition Berbasis Android pada SD Inpres Paccerakkang dapat menciptakan alat maupun metode pembelajaran baru dalam memahami rumus matematika Sekolah Dasar yang lebih interaktif dan menarik serta dapat membantu menyampaikan informasi rumus-rumus matematika Sekolah Dasar.

\section{TINJAUAN PUSTAKA}

\subsection{Aplikasi Mobile}

Menurut Agus Romdoni (2010:3), "Aplikasi mobile merupakan aplikasi yang dapat digunakan walaupun pengguna berpindah dengan mudah dari satu tempat ketempat lain tanpa terjadi pemutusan atau terputusnya komunikasi”.

Aplikasi ini dapat diakses melalui perangkat nirkabel seperti pager, telepon seluler dan PDA. Karakteristik perangkat mobile antara lain:

1. Ukurannya kecil

Perangkat mobile memiliki ukuran yang kecil. Konsumen menginginkan perangkat yang terkecil untuk kenyamanan dan mobilitas mereka.

2. Memori yang terbatas

Perangkat Mobile juga memiliki memory yang kecil, yaitu primary ( $R A M)$ dan secondary (disk).

3. Daya proses yang terbatas

Sistem mobile tidaklah setangguh rekan mereka yaitu dekstop.

4. Mengkonsumsi daya yang rendah

Perangkat mobile menghabiskan sedikit daya dibandingkan dengan desktop.

5. Kuat dan dapat diandalkan

\subsection{Matematika}

Menurut Herman Hudoyo (2003:123), Matematika merupakan suatu ilmu yang berhubungan ata menelaah bentuk-bentuk atau struktur-struktur yang abstrak dan hubungan-hubungan diantara hal-hal itu. Untuk dapat memahami struktur-struktur serta hubungan-hubungan, tentu saja diperlukan pemahaman tentang konsep-konsep yang terdapat di dalam matematika itu.

Ada beberapa pendapat yang menjelaskan tentang matematika salah satunya, matematika adalah ilmu tentang bilangan dan ruang, matematika merupakan bahasa simbol, matematika adalah bahasa numerik, matematika adalah ilmu yang abstrak dan deduktif, matematika adalah metode berpikir logis, matematika adalah ilmu yang mempelajari hubungan pola, bentuk dan struktur, matematika adalah ratunya ilmu dan juga menjadi pelayan ilmu yang lain.

Kata matematika berasal dari perkataan Latin mathematika yang mulanya diambil dari perkataan Yunani mathematike yang berarti mempelajari. Perkataan itu mempunyai asal katanya mathema yang berarti pengetahuan atau ilmu (knowledge, science). Kata mathematike berhubungan pula dengan kata lainnya yang hampir sama, yaitu mathein atau mathenein yang artinya belajar (berpikir). Jadi, 
berdasarkan asal katanya, maka perkataan matematika berarti ilmu pengetahuan yang didapat dengan berpikir (bernalar). Matematika terbentuk dari pengalaman manusia dalam dunianya secara empiris. Kemudian pengalaman itu diproses di dalam dunia rasio, diolah secara analisis dengan penalaran di dalam struktur kognitif sehingga sampai terbentuk konsep-konsep matematika supaya konsepkonsep matematika yang terbentuk itu mudah dipahami oleh orang lain dan dapat dimanipulasi secara tepat, maka digunakan bahasa matematika atua notasi matematika yang bernilai global (universal).

\subsection{Augmented Reality}

Menurut Furht Borko, Realitas tertambah atau Augmented Reality adalah teknologi baru yang melibatkan bagian dari komputer grafis dalam dunia nyata. Menurut Ronald Azuma, Augmented Reality adalah menggabungkan dunia nyata dan virtual, bersifat interaktif secara real time, dan merupakan animasi 3D. Paul Milgram dan Fumio Kishino pada tahun 1994, mendefinisikan Milgram's RealityVirtuality Continuum. Mereka menggambarkan sebuah kontinum yang membentang dari lingkungan nyata untuk untuk lingkungan virtual murni. Mereka menyimpulkan bahwa AR lebih dekat dengan dunia nyata dan augmented virtuality lebih dekat dengan dunia virtual.

Dalam penerapannya teknologi Augmented Reality memiliki beberapa komponen yang harus ada untuk mendukung kinerja dari proses pengolahan citra digital. Adapun komponen-komponen tersebut adalah sebagai berikut.

$\begin{array}{ll}\text { a. } & \text { Scene Generator } \\ \text { b. } & \text { Tracking System } \\ \text { c. } & \text { Display }\end{array}$

\subsection{Unity $3 D$}

Rickman Roedavan, Unity (2014:5), Unity Technologies dibangun ditahun 2004 oleh David Helgason, Nicolas Francis dan Joachim Ante. Game engine ini dibangun atas dasar kepedulian mereka terhadap indie developer yang tidak bias membeli game engine karena terlalu mahal.

\subsection{Database Cloud Recognition}

Cloud recognition adalah sebuah layanan untuk melakukan proses pengenalan terhadap image target yang dilacak menggunakan cloud database. Database sejumlah image target tidak lagi digabungkan dengan aplikasi sehingga lebih efisien. Selain itu jika terjadi perubahan terhadap informasi maka cukup dengan mengedit metadatanya saja bukan membongkar aplikasi. Cloud recognition target adalah gambar-gambar yang dijadikan marker atau markerless, diunggah pada cloud database. Vuforia kemudian melakukan query image target pada saat aplikasi dijalankan dan mengenali objek serta metadatanya.Cloud Recognition merupakan metode dalam mendeteksi AR. Dimana penyimpanan data setdari marker yang disimpan pada server harus dilakukan secara online.

\subsection{Unified Modeling Language (UML)}

Menurut Suhendar dan Hariman Gunadi (2011 : 10) Unified Modeling Language (UML) adalah sebuah bahasa untuk menetukan, visualisasi, kontruksi, dan mendokumentasikan artifact (bagian dari informasi yang digunakan atau dihasilkan dalam suatu proses pembuatan perangkat lunak. Artifact dapat berupa model, deskripsi atau perangkat lunak) dari sistem perangkat lunak,

seperti pada pemodelan bisnis dan sistem non perangkat lunak lainnya. UML merupakan suatu kumpulan teknik terbaik yang telah terbukti sukses dalam memodelkan sistem yang besar dan kompleks. UML tidak hanya digunakan dalam proses pemodelan perangkat lunak, namun hampir dalam semua bidang yang membutuhkan pemodelan.

UML sebagai sebuah bahasa yang memberikan vocabulary dan tatanan penulisan kata-kata dalam ' $M S$ Word' untuk kegunaan komunikasi. Sebuah bahasa model adalah sebuah bahasa yang mempunyai vocabulary dan konsep tatanan / aturan penulisan serta secara fisik mempresentasikan dari sebuah sistem. Seperti halnya UML adalah sebuah bahasa standard untuk pengembangan sebuah software yang dapat menyampaikan bagaimana membuat dan membentuk model-model, tetapi tidak menyampaikan apa dan kapan model yang seharusnya dibuat yang merupakan salah satu proses implementasi pengembangan software. 


\subsection{Konsep Android}

Menurut Hermawan S. (2011:73), Android adalah sistem operasi yang digunakan di smartphone dan juga tablet PC. Android pertama kali dikembangkan oleh perusahaan bernama Android Inc., dan pada tahun 2005 di akuisisi oleh raksasa Internet Google. Android dibuat dengan basis kernel Linux yang telah dimodifikasi, dan untuk setiap release-nya diberi kode nama berdasarkan nama hidangan makanan. Keunggulan utama Android adalah gratis dan open source. Keuntungan open source, banyak pengembang software yang bisa melihat dan memanfaatkan kode itu serta bisa membuat aplikasi baru di dalamnya. Berbagai aplikasi android diwadahi dalam sebuah portal, yaitu Android Market, sehingga pengguna tinggal meng-install aplikasi pilihannya.Arsitektur pengembangan alikasi android diperlihatkan pada gambar

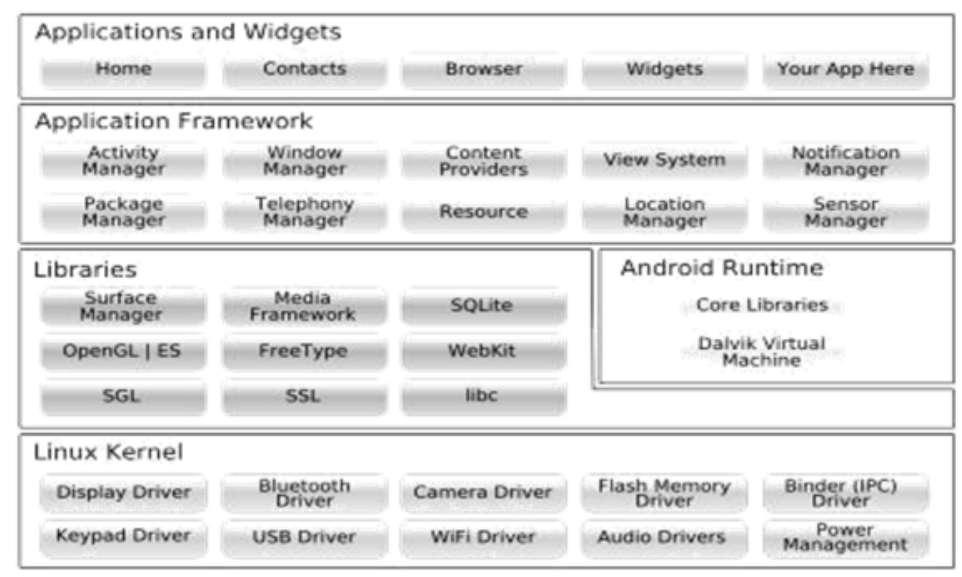

Gambar 2.1 Arsitektur Android

\subsection{Teknik Pengujian Black Box}

Teknik pengujian yang digunakan dalam menyusun skripsi ini adalah teknik pengujian Black Box. Salah satu metode pengujian perangkat lunak adalah

Black-Box Testing. Black-box Testing merupakan sebuah metode yang digunakan untuk menemukan kesalahan dan mendemonstrasikan fungsional aplikasi saat dioperasikan, apakah input diterima dengan benar dan output yang dihasilkan telah sesuai dengan yang diharapkan.

Fokus dari pengujian mengunakan metode Black-Box adalah pada pengujian fungsionalitas dan output dihasilkan aplikasi. Pengujian black-box didesain untuk mengungkap kesalahan pada persyaratan fungsional dengan mengabaikan mekanisme internal atau komponen dari suatu program.

Salah satu dari pengujian Black-Box yang dapat dilakukan oleh seorang penguji independen adalah Functional testing. Basis uji dari functional testing ini adalah pada spesifikasi dari komponen perangkat lunak yang akan diuji

\section{METODE PENELITIAN}

Dalam rangka keberhasilan penelitian, maka digunakan dua jenis metode penelitian untuk pengumpulan data yaitu :

\section{Penelitian pustaka}

Penelitian dilakukan melalui buku-buku pustaka dan internet yang dapat memberikan teori-teori mengenai sistem yang diteliti, kemudian mencocokkan dengan kemungkinan-kemungkinan yang terjadi dalam usaha penyelesaian masalah.

\section{Penelitian lapangan}

Penelitian yang dilakukan dengan mengunjungi langsung lokasi penelitian. Di tempat penelitian tersebut penulis melakukan pengamatan langsung terhadap objek penelitian dan melakukan

\subsection{Teknik Pengumpulan Data}

Pengumpulan data adalah salah satu hal yang penting dilakukan dalam memperoleh data yang diinginkan. Data yang dikumpulkan tersebut akan menjadi sebuah basis data. Dengan adanya data yang diambil tersebut, akan sangat membantu sebagai bahan pertimbangan dalam perancangan sistem informasi. Adapun teknik yang digunakan dalam pengumpulan data yaitu : 
1. Teknik Wawancara

Teknik ini merupakan suatu teknik pengumpulan data dengan cara mewawancarai staf perparkiran di beberapa tempat di makassar

2. Teknik Observasi

Teknik ini merupakan suatu teknik pengumpulan data dengan cara mengamati dan melihat langsung kegiatan atau proses yang terjadi di perparkiran di Makassar

\subsection{Alat dan Bahan Penelitian}
1. Alat Penelitian:
a. Hardware
1. 1 unit Notebook
2. Processor AMD Athlon (tm) X2 Dual-Core QL-64(2 CPUs), $2.1 \mathrm{GHz}$
3. Memory RAM DDR 2 GigaByte
4. Harddisk $250 \mathrm{~GB}$
5. Handphone Android
b. Software
1. Eclipse
2. Android SDK
3. Moodle
4. Web Server Xampp
2. Bahan Penelitian
1. Data Mata Kuliah
2. Materi Kuliah
3. Data Dosen

\subsection{Metode Pengujian Sistem}

Menurut Roger S. Pressman (2010: 551) dalam buku rekayasa perangkat lunak yang menyatakan "pengujian black box berfokus pada persyaratan fungsional perangkat lunak". Dengan demikian, pengujian black box memungkinkan perekayasa perangkat lunak mendapatkan serangkaian kondisi input yang sepenuhnya menggunakan semua persyaratan fungsional untuk suatu program. Pengujian black box bukan merupakan alternative dari teknik white box, tetapi merupakan pendekatan komplementer yang kemungkinan besar mampu mengungkap kelas kesalahan dari pada metode white box

\section{HASIL DAN PEMBAHASAN}

Aplikasi Pembelajaran Rumus Matematika Menggunakan Teknologi Augmented Reality Dengan Database Cloud Recognition Berbasis Android Pada SD Inpres Paccerakkang ini, merupakan aplikasi yang akan diimplementasikan kedalam teknologi 3 dimensi dan 2 dimensi yang dapat memberikan anak pengetahuan dan pembelajaran matematika dengan cara yang menyenangkan yaitu "bermain sambil belajar".

Aplikasi ini menampilkan objek rumus matematika dalam bentuk 3 dimensi serta berisi sedikit penjelasan dari rumus matematika tersebut dan bentuk 2 dimensi yang berisi materi pembelajaran dan Quiz sebagai bahan evaluasi. Terdapat lima menu utama yaitu, menu Start Scan ( Scan Flash Card), menu Study, menu Quiz, menu Help, dan menu Info. Langkah-langkah pengoperasian Aplikasi Pembelajaran Rumus Matematika Menggunakan Teknologi Augmented Reality Dengan Database Cloud Recognition Berbasis Android Pada SD Inpres Paccerakkangantara lain :

\section{Menu Start Scan :}

1. Siapkan buku marker rumus matematika.

2. Aktifkan data Internet HP.

3. Buka aplikasi.

4. Pilih menu "Start Scan" untuk memulai men-scan marker.

5. Kamera akan mulai mendeteksi marker.

6. Setelah terdeteksi, maka akan tampil objek 3D Rumus Matematika berdasarkan marker yang digunakan beserta voice dari rumus tersebut. 
7. Jika tombol informasi ditekan maka akan mucul papan informasi sesuai dengan objek 3D yang telah terdeteksi.

8. Objek 3D bias diputar dan di perbesar dan diperkecil.

\section{Menu Study :}

1. Buka Aplikasi

2. Pilih menu Study (Gambar Buku)

3. Maka akan muncul pemilihan Kelas (Kelas 4, 5, 6)

4. Setelah memilih kelas, maka akan tampil materi pelajaran.

\section{Menu Quiz :}

1. Buka Aplikasi

2. Pilih menu Quiz

3. Membaca aturan penggunaan quiz

4. Terdapat 20 soal setiap soal mempunyai batak waktu menjawab selama dua menit.

5. Terdapat 5 kesempatan salah menjawab, jika lewat dari 5 maka Quiz akan berhenti dan menampilkan score.

\section{Menu Help :}

1. Buka Aplikasi

2. $\quad$ Pilih menu Help

3. Maka akan muncul button, disetiap button akan menampilkan fungsi button tersebut.

\subsection{Use Case Diagram}

Use case pada aplikasi berhubungan dengan aplikasi dan penggunaan augmented reality pada aplikasi. Dimana augmented reality digunakan dalam memanipulasi obyek-obyek maya dengan berinteraksi dengan obyek fisik di lingkunga nnyata.

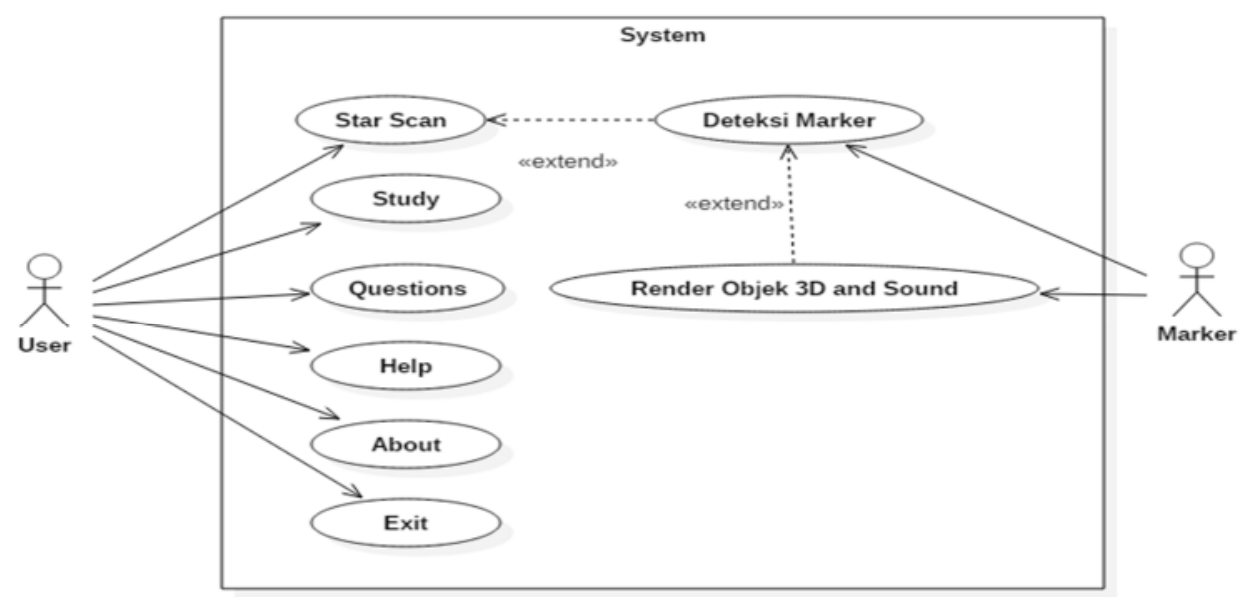

Gambar 4.1 Use Case Diagram Pada Sistem e-learning

\subsection{Activity Diagram}

Activity Diagram menggambarkan berbagai alur aktifitas dalam sistem yang sedang dirancang, bagaimana masing-masing alur, decision yang mungkin terjadi, dan bagaimana mereka berakhir. Activity diagramnya dapat dilihat pada gambar berikut 
1. Activity Diagram Study

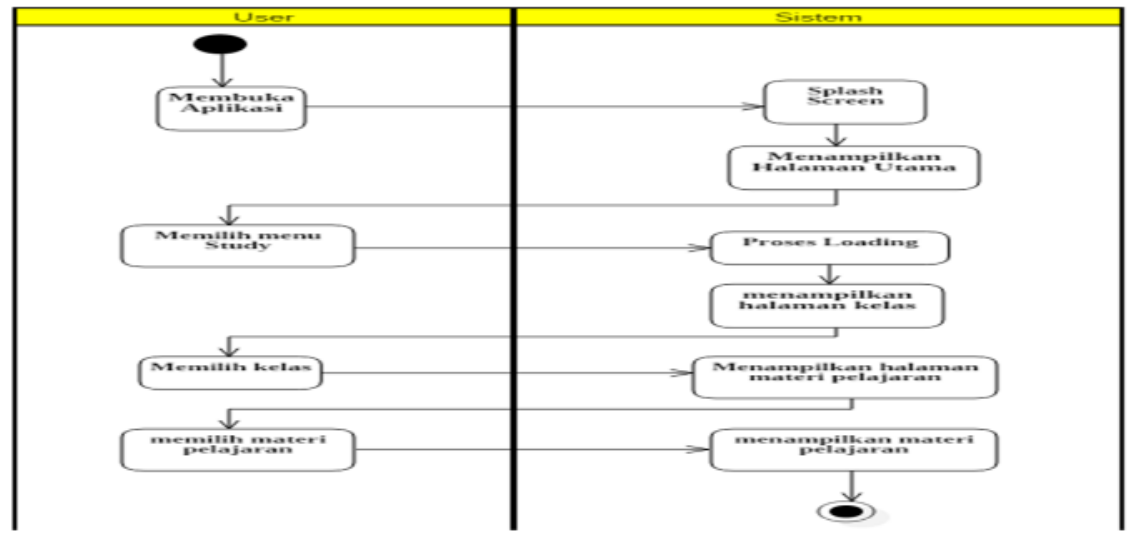

Gambar 4.2 Activity Diagram Study.

2. Activity Diagram Start Scan

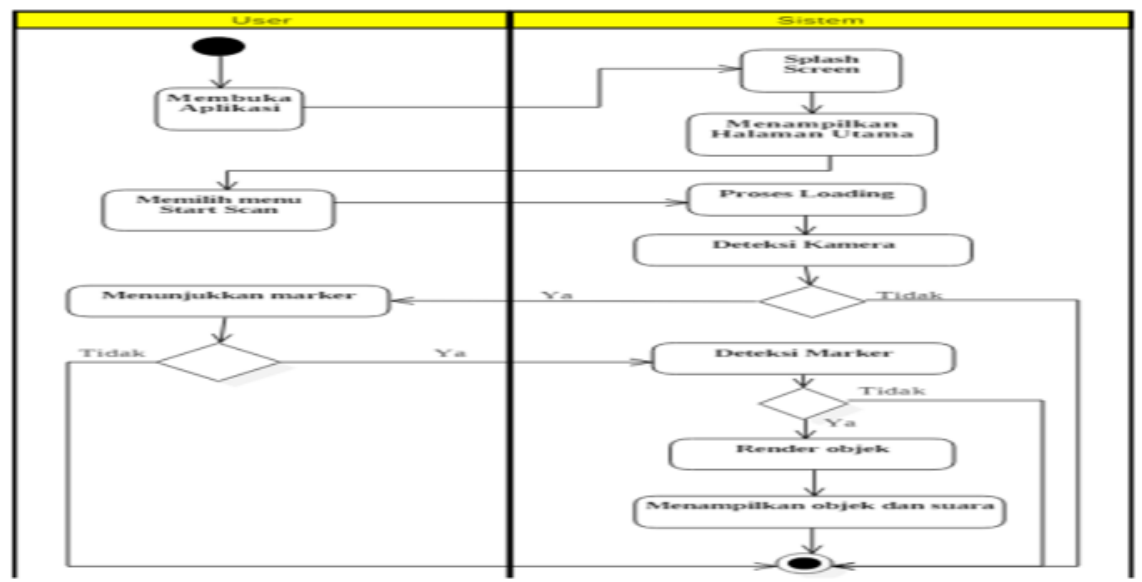

Gambar 4.3 Activity Diagram Start Scan.

3. Subactivity Diagram Render Objek dan Suara

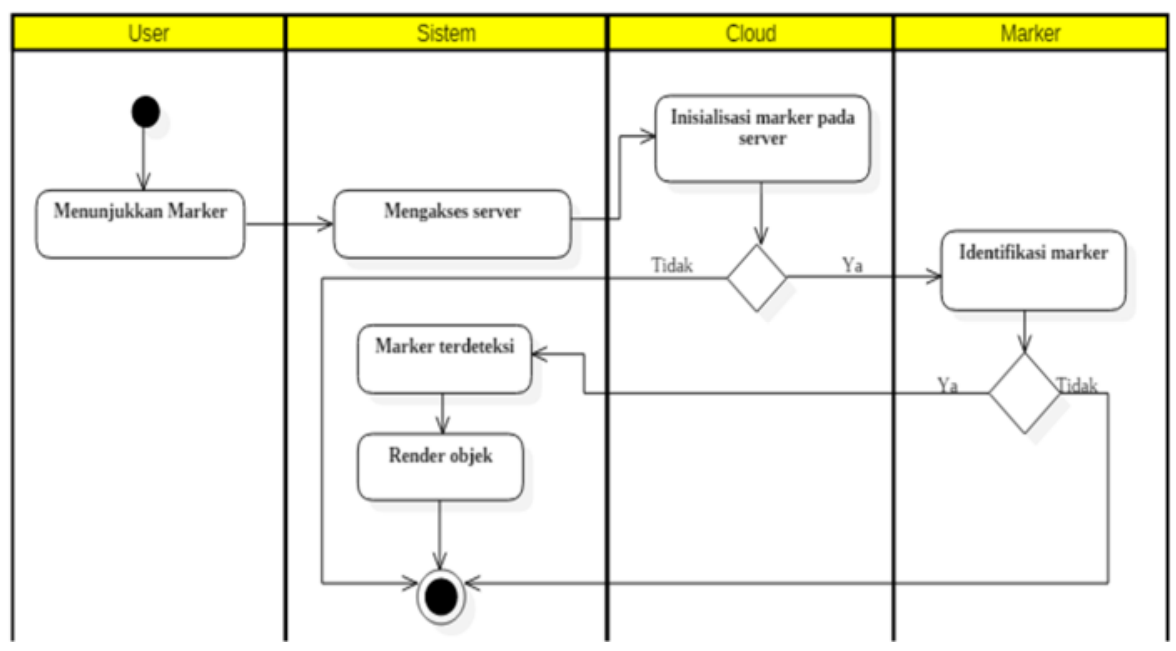

Gambar 4.4 SubactivityDiagram Render Objek dan Suara. 


\subsection{Sequence Diagram}

\section{Sequence Diagram Study}

Gambar Sequence Diagram Info dapatdilihatpadagambar4.15.

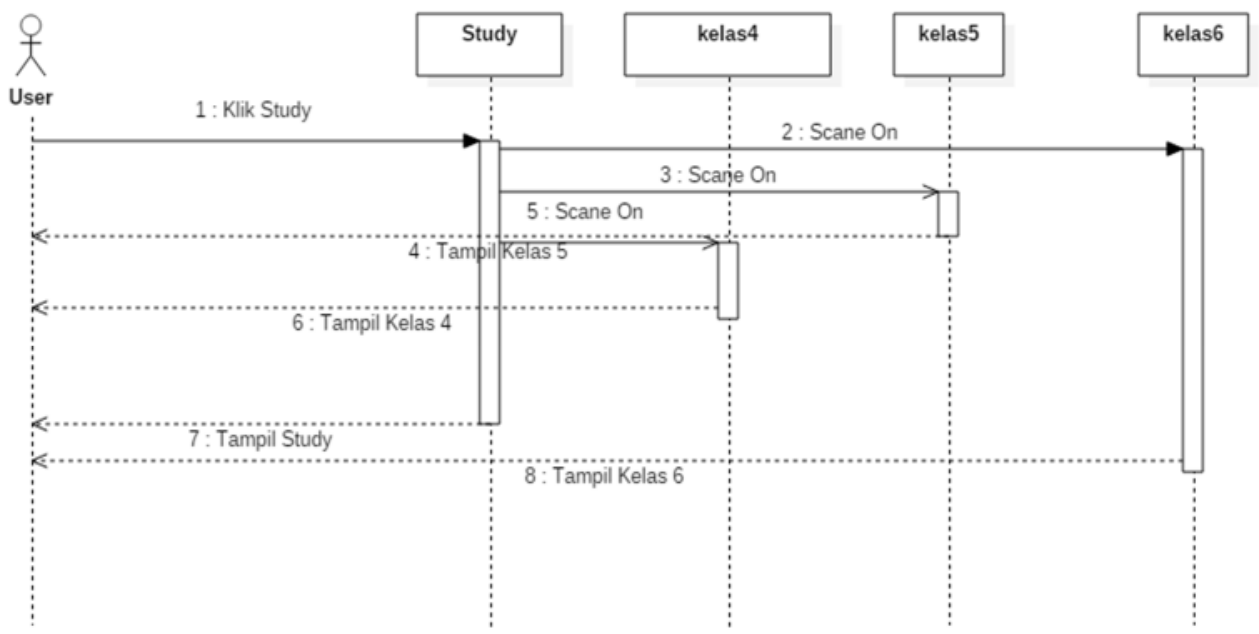

Gambar 4.5 Sequence Diagram Study.

\section{Sequence Diagram Start Scan}

Gambar Sequence Diagram Start Scan dapatdilihatpadagambar

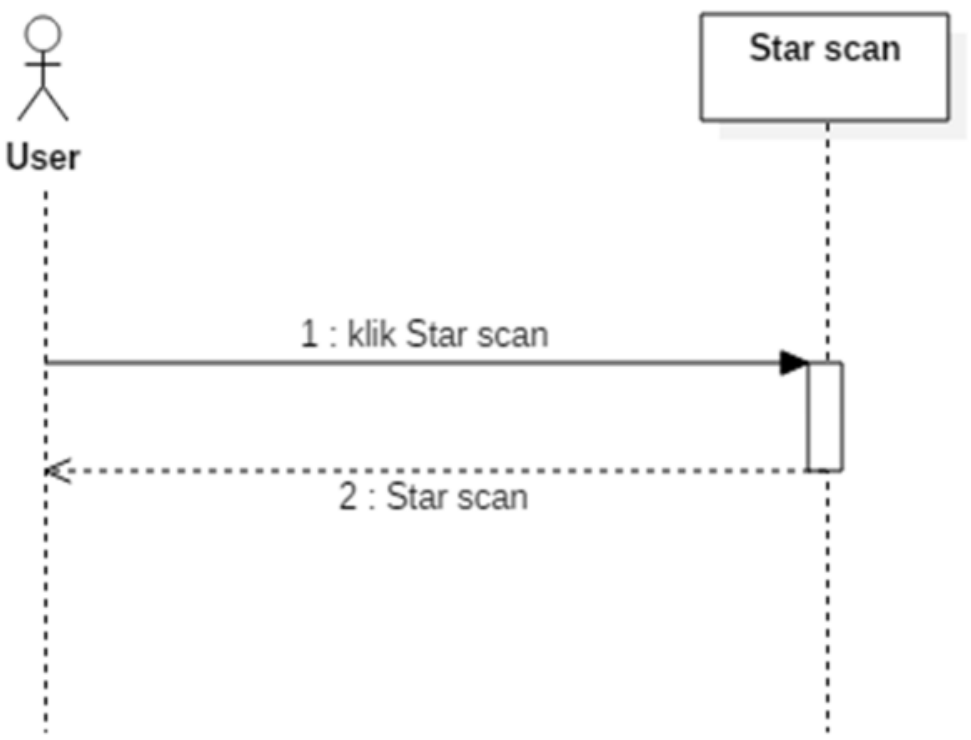

Gambar 4.6 Sequence Diagram Star Scan.

\subsection{Class Diagram}

Class diagram adalah sebuah spesifikasi yang jika diinstansiasi akan menghasilkan sebuah objek dan merupakan inti dari pengembangan dan desain berorientasi objek. Class menggambarkan keadaan (attribute atau property) suatu sistem, sekaligus menawarkan layanan untuk memanipulasi keadaan tersebut (metoda atau fungsi). Gambar 4.18 adalah kelas diagram dari Aplikasi Pembelajaran Rumus Matematika Menggunakan Teknologi Augmented Reality Dengan Database Marker Cloud Recognition Berbasis Android Pada SD Inpres Paccerakkang. 


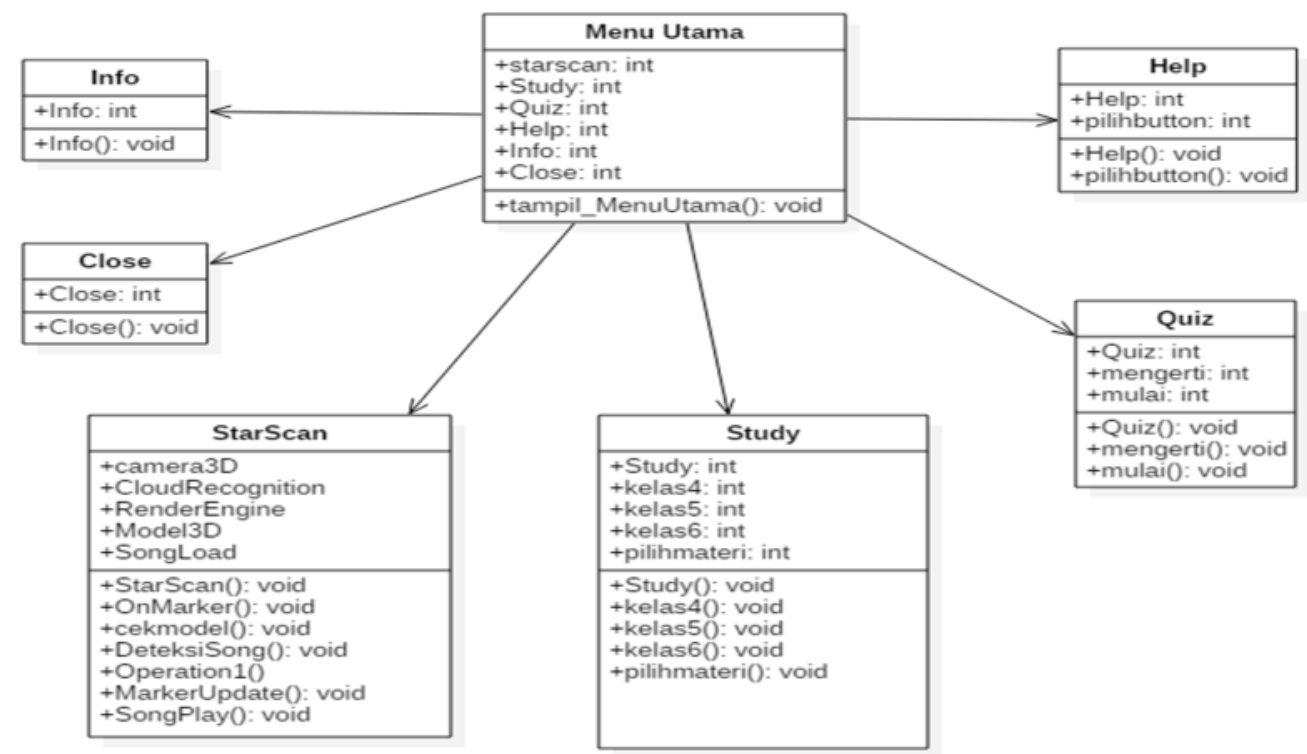

Gambar 4.7 Class Diagram Aplikasi rumus matematika.

\section{Metode Pengujian Sistem}

Pengujian Sistem yang dilakukan dengan menggunakan metode pengujian langsung berdasarkan teknik BlackBox dengan menguji fungsionalitas dari aplikasi,tombol dan kesesuaian hasil aplikasi.

a. PengujianPadaMenu Utama Program

Tabel 4.1 Tampilan Menu Utama Program

\begin{tabular}{|c|c|c|}
\hline Test Factor & Hasil & $\begin{array}{c}\text { Keterangan } \\
\text { Uerhasilmenentukan Menu } \\
\text { Utama Program }\end{array}$ \\
\hline Menjalankan Program & Screenshoot \\
\hline
\end{tabular}

\section{2. $\quad$ PengujianPadaMenu Help Program}

Tabel 4.2 Tampilan Menu HelpProgram.

\begin{tabular}{|c|c|c|}
\hline Test Factor & Hasil & Keterangan \\
\hline MengklikButtonHelp & $\sqrt{ }$ & Berhasilmenentukan Menu \\
& Help Program \\
\hline
\end{tabular}




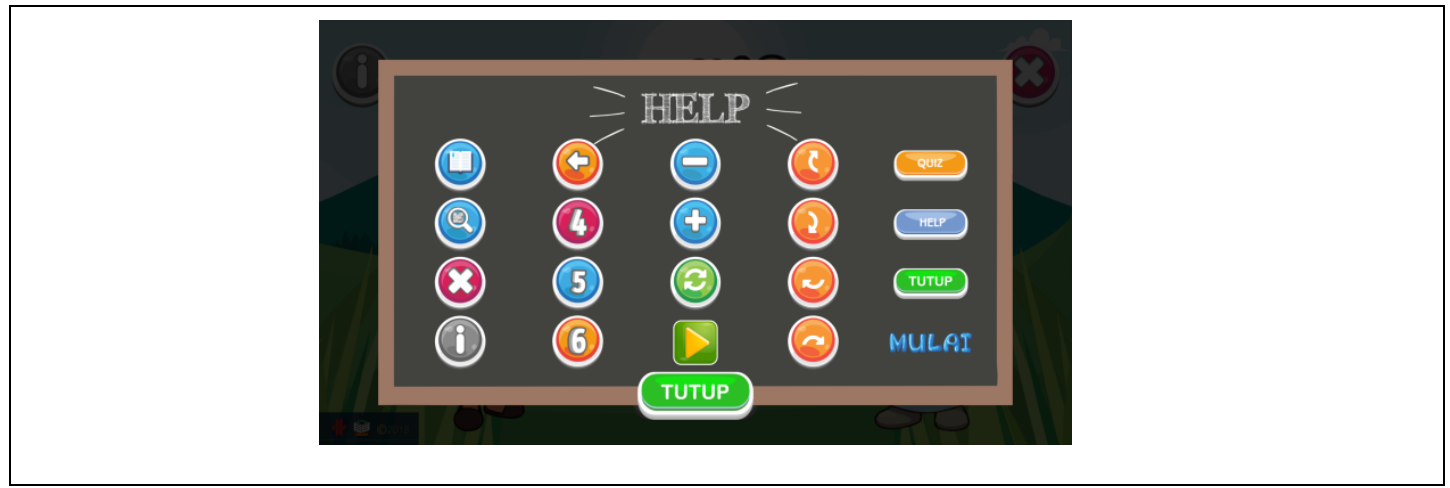

3. PengujianPadaMenu Study Program

Tabel 4.3 Tampilan Menu StudyProgram.

\begin{tabular}{|c|c|c|}
\hline Test Factor & Hasil & $\begin{array}{c}\text { Keterangan } \\
\text { Study Program }\end{array}$ \\
\hline MengklikButtonStudy & Screenshoot \\
\hline
\end{tabular}

\section{Pengujian Menu Kelas 4Program}

Tabel 4.4 Tampilan Menu Kelas 4 Program

\begin{tabular}{|c|c|c|}
\hline Test Factor & Hasil & Keterangan \\
\hline $\begin{array}{l}\text { Mengklik Button } 4 \text { Pada Menu } \\
\text { Study }\end{array}$ & $\sqrt{ }$ & $\begin{array}{l}\text { Berhasil menampilkan Menu } \\
\text { Kelas } 4\end{array}$ \\
\hline \multicolumn{3}{|c|}{ Screenshoot } \\
\hline \multicolumn{3}{|c|}{ KEETLAS 4} \\
\hline \multirow{4}{*}{ (3) हु } & $D$ & (N) \\
\hline & D) Geometri dan Pengukuran & \\
\hline & Penjumlahan \& Pengukuran Bilangan Bulat & \\
\hline & $D$ Bilangan Pecahan & \\
\hline & Bilangan Romawi & \\
\hline & D Sifat Bangun \& Hubungan Antar Bangun & \\
\hline \multicolumn{3}{|c|}{ 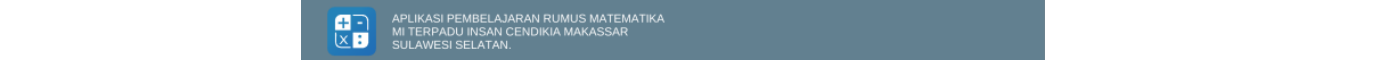 } \\
\hline
\end{tabular}

Tabel 4.5 Mendeteksi Objek 3D.

\begin{tabular}{|c|c|c|}
\hline Test Factor & Hasil & Keterangan \\
\hline Mendeteksi Marker & $\sqrt{ }$ & Berhasil mendeteksi Marker \\
& & \\
\hline
\end{tabular}




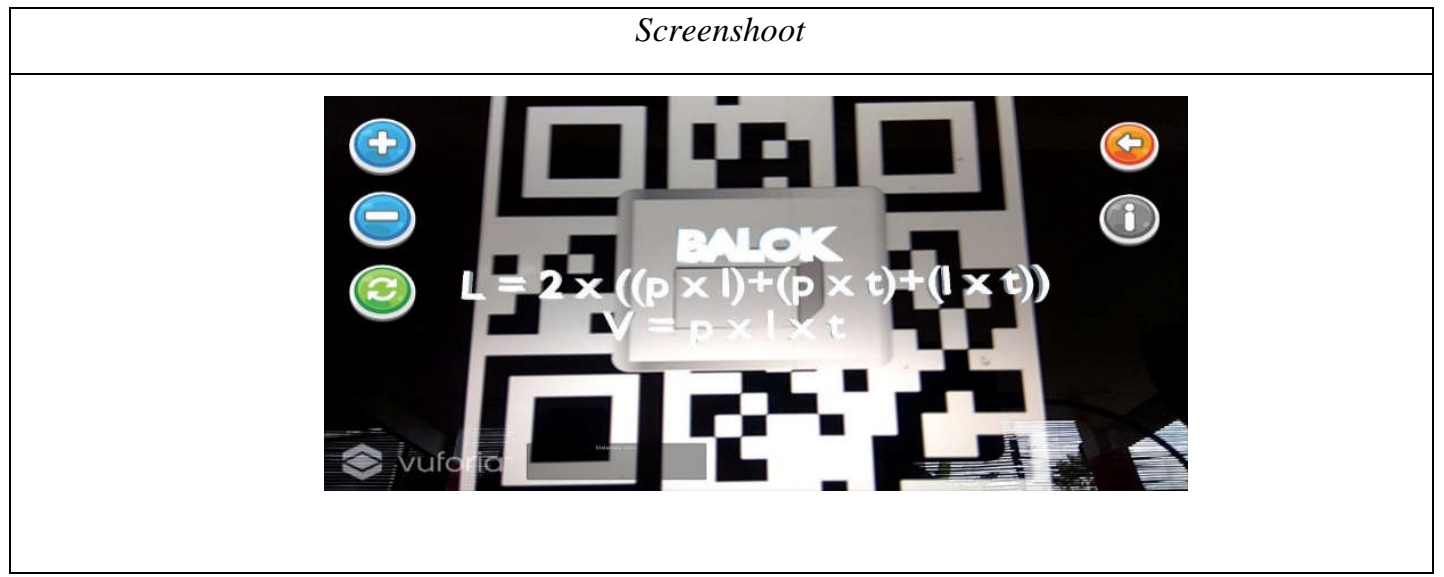

\section{KESIMPULAN DAN SARAN}

\section{Kesimpulan}

Berdasarkan pengamatan dan pembahasan penulis selama mengadakan penelitian SD Inpres Paccerakkang dan dari hasil teknik uji coba Black box yang diambil dengan melihat permasalahan yang ada, maka dapat diambil suatu kesimpulan sebagai berikut :

1. Aplikasi yang dibangun ini dapat memberikan kemudahan bagi siswa-siswi untuk memperoleh ilmu pengetahuan dan informasi kapanpun dimanapun mereka berada secara cepat.

2. Aplikasi ini menggunakan satu hak akses yaitu User.

3. Dengan menggunakan implementasi teknologi Augmented Reality ini dapat menjadi inovasi baru bagi siswa-siswi SD Inpres Paccerakkang untuk mendapatkan ilmu pengetahuan.

4. Setelah dilakukan pengujian menggunakan metode BlackBox di dapatkan hasil dari semua pengujian yang sesuai dengan indicator yang diharapkan.

\section{Saran}

Adapun saran-saran sebagai berikut:

1. Peneliti menilai bahwa aplikasi ini masih jauh dari kesempurnaan baik dari segi fungsionalitas maupun data yang dimiliki, maka diharapkan masukan dari pembaca yang sifatnya membangun agar penulis selalu meningkatkan kemampuannya.

2. Adapun saran yang dapat diberikan guna penelitian lebih lanjut tentang program ini adalah dengan mengujicobakan pada data yang berbeda dengan jumlah data yang lebih besar, dan membandingkan penyimpanan pada Cloud.

\section{DAFTAR PUSTAKA}

[1] A.Suhendra, Hariman Gunadi. 2011. "Visual Modelling Menggunakan UML dan Rational Rose". Jakarta, Informatika.

[2] Borko, Furht. 2011. "Handbook of Augmented Reality, Department of Computer and Electrical Engineering and Computer Science". Florida. Florida Atlantic University.

[3] Hudoyo, Herman. 2003. "Pengembangan Kurikulum dan Pembelajaran Matematika". Malang: Universitas Negeri Malang.

[4] Irawan. 2013. "Membuat Aplikasi Android Untuk Orang Awam". Palembang : Maxikom.

[5] Munadi, Yudhi. 2008. Media Pembelajaran:suatu pendekatan baru. Jakarta:Gaung Persada Press.

[6] Roedavan, Richman. 2014. "Unity Tutorial Game Engine". Bandung: Informatika.

[7] Roger S. Pressman. 2010. "Metode Pengujian Sistem". Jakarta.

[8] Romdoni, Agus. 2010. "Pengertian Aplikasi Mobile". Jakarta. Third Edition. 